\title{
Policy responses to foodborne disease outbreaks in the United States and Germany
}

\author{
Kelsey D. Meagher ${ }^{1}$ iD
}

Accepted: 21 June 2021 / Published online: 9 July 2021

(c) The Author(s) 2021

\begin{abstract}
This paper explores differences in national responses to foodborne disease outbreaks, addressing both the sources of policy divergence and their implications for public health and coordinated emergency response. It presents findings from a comparative study of two multi-state E. coli outbreaks, one in the United States (2006) and one in Germany (2011), demonstrating important differences in how risk managers understood and responded to each nation's first major outbreak associated with fresh produce. Drawing on a qualitative analysis of 36 semi-structured interviews with key stakeholders and hundreds of archival documents, this paper traces how social constructions of the E. coli risk interacted with organizational dynamics among state and industry actors to produce divergent policy outcomes: the U.S. outbreak was understood primarily as an agricultural problem that led to an industry-led agricultural solution, whereas the German outbreak was understood as a human disease problem that did not result in a substantial policy response once the acute health crisis passed. The paper concludes by discussing how these policy processes generate partial solutions to foodborne contamination that expose modern societies to systemic vulnerabilities.
\end{abstract}

Keywords Food safety $\cdot$ Governance $\cdot$ Food policy $\cdot$ Foodborne disease outbreaks $\cdot$ United States $\cdot$ Germany

$\begin{array}{ll}\text { Abbreviations } \\ \text { BfR } & \begin{array}{l}\text { Bundesinstitut für Risikobewertung (German } \\ \text { Federal Institute for Risk Assessment) }\end{array} \\ \text { BMELV } & \begin{array}{l}\text { Bundesministerium für Ernährung, Land- } \\ \text { wirtschaft, und Verbraucherschutz (German }\end{array} \\ & \text { Federal Ministry for Food, Agriculture, and } \\ & \text { Consumer Protection) } \\ \text { BSE } & \begin{array}{l}\text { Bovine spongiform encephalopathy ("mad cow } \\ \text { disease") }\end{array} \\ \text { BVL } & \begin{array}{l}\text { Bundesamt für Verbraucherschutz und Leb- } \\ \text { ensmittelsicherheit (German Federal Office of }\end{array} \\ \text { CDC } & \begin{array}{l}\text { Consumer Protection and Food Safety) } \\ \text { U.S. Centers for Disease Control and }\end{array} \\ \text { EHEC } & \begin{array}{l}\text { Prevention } \\ \text { EUterohemorrhagic Escherichia coli } \\ \text { FDA }\end{array} \\ \text { EAP } & \begin{array}{l}\text { European Union } \\ \text { Good Agricultural Practice }\end{array}\end{array}$

Kelsey D. Meagher

kdmeagher@ucdavis.edu

1 Department of Food Science and Technology, University of California, Davis, One Shields Avenue, Davis, CA 95616, USA

$\begin{array}{ll}\text { FSMA } & \text { Food Safety Modernization Act (2011) } \\ \text { HACCP } & \text { Hazard Analysis and Critical Control Points } \\ \text { HUS } & \text { Hemolytic uremic syndrome } \\ \text { LGMA } & \text { Leafy Greens Marketing Agreement } \\ \text { NASA } & \text { U.S. National Aeronautics and Space } \\ & \text { Administration } \\ \text { RKI } & \text { Robert Koch Institut } \\ \text { USDA } & \text { U.S. Department of Agriculture }\end{array}$

Responses to foodborne disease outbreaks vary substantially across national regulatory regimes despite a nearly universal desire to eradicate foodborne illness. In a globalized food system, international policy differences can profoundly impact the safety of the food supply, international trade disputes, and the coordinated management of large-scale outbreaks. This paper seeks to improve our understanding of cross-national differences in food safety governance through a comparative analysis of policy responses to two major E. coli outbreaks: the 2006 U.S. E. coli outbreak linked to bagged spinach, and the 2011 German $E$. coli outbreak linked to fenugreek sprouts. These outbreaks represented each nation's first large-scale outbreak linked to fresh produce, as previous outbreaks had mostly involved meat 
and poultry products. Fresh produce is often eaten raw and therefore lacks a "kill step" to neutralize pathogens, so the 2006 and 2011 outbreaks represented a fundamentally new challenge for U.S. and German regulatory regimes.

This paper analyzes 36 semi-structured interviews with key stakeholders and hundreds of archival documents to examine how stakeholders defined and sought to control food risks following the 2006 and 2011 outbreaks. The analysis traces how social constructions of the crises interacted with organizational dynamics among state and industry actors to produce divergent policy outcomes. Despite striking similarities in the nature of the threat and the formal organization of food safety controls, national responses to the outbreaks diverged: The U.S. outbreak was framed primarily as an agricultural problem, whereas the German outbreak was framed as an infectious disease problem, and these differences shaped institutional responses to the outbreak. U.S. stakeholders created an industry-led program for farm-level controls, whereas German stakeholders updated a few processes for disease reporting and product tracing but avoided enacting more substantial reforms. In the absence of substantial public engagement, both policy outcomes largely reinforced the institutional status quo, which differs crossnationally. Although the U.S. response outpaced the German response in terms of attempting to prevent future contamination, both nations failed to address structural causes of large-scale contamination that leave them vulnerable to future outbreaks (DeLind and Howard 2008; Korinek and Strassheim 2013).

These cases challenge the common assumption that large-scale crises yield large-scale reforms and that cultural commitments to the "precautionary principle" imply a preventative approach to all matters of consumer protection (Brickman et al. 1985; Burri 2015; Science for Environment Policy 2017). The cases also offer important theoretical insights about how and why policy responses to foodborne risks diverge cross-nationally. Findings reveals that practitioners in each nation shared similar goals and expertise, but their understandings of the problem and solution were shaped by important differences in each regulatory regime's structure and context (Hood et al. 2001). The analysis reinforces previous insights about the timing and nature of policy learning after crisis (Birkland 1997; Jasanoff 2007; Kingdon 1997), and it also clarifies how regulatory regimes influence the management of an important yet understudied policy domain involving both public and private risk management schemes (Ansell and Baur 2018; Verbruggen and Havinga 2017). By contextualizing the observed policy responses within a broader range of plausible (yet unchosen) responses, the analysis exposes how food risks can be constructed as "non-problems" whose solutions fail to disrupt existing dynamics of technocratic governance (Baur 2021; DeLind and Howard 2008; Freudenburg 2000; Jones and
Davidson 2014). Altogether, this paper aims to leverage multiple points of comparison (across nations, organizational contexts, and policy alternatives) to clarify how and when crises reshape national food policy.

\section{U.S. and German experiences with large-scale produce outbreaks}

\section{U.S. outbreak of E. coli 0157:H7 in spinach (2006)}

In September 2006, an outbreak of E. coli O157:H7 in raw bagged spinach caused at least 276 illnesses and 5 deaths in North America (CDC 2006b). Consumers in 26 states and one Canadian province were affected. The U.S. Food and Drug Administration (FDA) immediately called for retailers to remove bagged spinach from stores and warned consumers not to eat fresh spinach, marking the first time that an FDA advisory singled out an entire product category rather than a specific brand or product (CDC 2006a). Investigators ultimately traced the outbreak to bagged spinach that had been packaged in a single California facility (owned by Natural Selection Foods) and sourced from one farm (CalFERT 2007).

Media coverage of the outbreak focused on explaining the FDA advisory, the status of the investigation, and possible causes of contamination (Nucci et al. 2009; Todd et al. 2007). The outbreak was most often framed as a problem with agricultural production, with experts describing potential sources of contamination on the farm and emphasizing that the ultimate cause might never be known: "I'm hopeful we will find a cause, but there's a realistic possibility we won't," said an FDA official (Shin and Geis 2006). With public attention focused on farm-level issues more than on other parts of the supply chain, key stakeholders began to call for new farm-level food safety controls (Shin 2006; Weise 2007).

California state legislators drafted three bills to address farm-level food contamination, but they failed in committee once legislators decided to support a parallel, industrydriven action. The California leafy greens industry, led by the Western Growers Association with support from other trade associations, began developing "good agricultural practices" (GAPs) to reduce the risk of contamination, an effort that culminated in the California Leafy Greens Marketing Agreement (LGMA). The LGMA set microbial limits for water and soil amendments and established best practices for handling other possible sources of contamination, including animal intrusions, workers, harvest equipment, and climatic conditions. The LGMA standards built upon broadly defined GAPs developed previously by the FDA (1998) and industry associations (International Fresh-Cut Produce Association et al. 2006), which had themselves been 
generalized from a 1970s-era management model known as Hazard Analysis and Critical Control Points (HACCP). HACCP systems require operators to identify all potential contamination points in their production processes and implement corresponding controls. ${ }^{1}$

Supporters of the LGMA described it as a model public-private partnership that would dramatically reduce the risk of future outbreaks; because industry experts created the guidelines and government inspectors enforced them, supporters believed that the LGMA would remain credible to industry members while maintaining regulatory "teeth." However, critics argued that the LGMA interfered with onfarm conservation practices, was financially burdensome for small-scale growers, and ignored the critical role of food processors in spreading the contamination (Cohen 2008; DeLind and Howard 2008; Karp et al. 2015). The final investigative report revealed that the processing facility failed to follow several procedures that could have mitigated the contamination (CalFERT 2007), yet regulators and industry representatives believed that farms represented a greater regulatory gap than processing facilities. ${ }^{2}$ One interviewee explained, "There were discussions about whether LGMA should go into the processing facilities as well, but the decision was made: No, we're going to keep our eye on the ball, and that is the area where there is no oversight or regulation, so we focused on the farm."

U.S. marketing agreements typically standardize commodity production or packaging, but the LGMA re-purposed the policy instrument to regulate food safety. Marketing agreements are voluntary, but they become binding for signatories. Due to the concentrated power of U.S. retailers, who began requiring LGMA membership from leafy greens suppliers, the legally voluntary standards soon became mandatory in practice. Just 2 years after the outbreak, over $99 \%$ of the leafy greens grown in California were produced by LGMA signatories, and California produces $75 \%$ of leafy greens grown in the U.S. (Calvin 2007). Smaller growers who sell through direct marketing channels (e.g., farmers'

\footnotetext{
${ }^{1}$ HACCP systems were first developed by NASA and the Pillsbury Company to ensure safe food for astronauts. Federal authorities later mandated HACCP systems for canned foods, seafood, juices, and raw meat after outbreaks in the 1970s-1990s; the 2011 Food Safety Modernization Act now requires all processing facilities to develop HACCP-based systems. In Europe, food operators have been required to implement HACCP systems since 1993 (Council Directive 93/43/ EEC).

2 At the time of the outbreak, FDA had limited authority over farms: FDA officials could inspect farms during active outbreak investigations, but they lacked authority to conduct routine inspections or mandate controls. Processors were already covered under FDA regulations, although it was widely acknowledged that FDA lacked resources to adequately monitor the more than 50,000 food facilities subject to their oversight (DHHS 2010). Federal authority over farms was later expanded with the 2011 Food Safety Modernization Act.
}

markets and farm stands) were not bound by the standards, but their opportunities for expanding into wholesale markets were curtailed and they lost access to the Canadian market once Canada banned imports from non-LGMA signatories.

LGMA's policy impact extended beyond California leafy greens by inspiring similar agreements in other regions and commodities. It also inspired many of the standards in the 2011 Food Safety Modernization Act (FSMA), the first major reform of federal food safety legislation in over a halfcentury (Lytton 2019a). Although the LGMA still earned praise from interviewees for its timely, collective response to a public health crisis, its longer-term impact on food safety is more difficult to assess. Several multi-state outbreaks have been traced to leafy greens over the last decade (Marshall et al. 2020), though it is impossible to determine whether additional outbreaks would have occurred in the absence of the LGMA.

\section{German outbreak of $E$. coli $0104: \mathrm{H} 4$ in sprouts (2011)}

In May and June 2011, an outbreak of a rare and virulent strain of E. coli occurred in northern Germany (Robert Koch Institut 2012). Many victims developed bloody diarrhea and hemolytic uremic syndrome (HUS), a serious kidney condition. Clinicians noted that the earliest victims were middleaged women, in contrast to the infant and elderly victims more typical of HUS outbreaks. The outbreak eventually sickened nearly 4000 people and 53 people died, making it the largest $E$. coli outbreak in German history and one of the largest globally.

Within days of the first case reports, epidemiologists from the Robert Koch Institut (RKI) conducted a preliminary investigation and concluded that the outbreak was not linked to the usual suspects of meat or dairy products. Instead, their findings suggested that the source might be tomatoes, lettuce, cucumbers, or something normally eaten with these foods. A Hamburg official prematurely announced that Spanish cucumbers were the outbreak vehicle, but they had not yet serotyped the E. coli samples. Later, it was discovered to be a pathogenic strain unrelated to the outbreak strain. This mistake drew intense criticism from Spanish growers, who demanded financial compensation for their losses (The Telegraph 2011).

Outbreak investigators eventually determined that the most likely source was sprouts grown from imported fenugreek seeds from Egypt (BfR 2012). Their conclusion was based only on epidemiological evidence, as microbiological samples never tested positive for the pathogen. Experts explained the lack of microbiological evidence by pointing to the short shelf-life of sprouts (i.e., most were eaten or discarded before the outbreak was identified) and the lack of verified tests for this rare $E$. coli strain. However, the lack of physical evidence 
left some with lingering doubts, especially the Egyptians who resisted Germany's temporary ban on Egyptian seed imports (The Local 2011b).

Despite the magnitude of human and financial losses associated with the outbreak, few called for policy reforms. Media coverage framed the outbreak primarily as a public health problem, focusing on investigators' efforts to isolate the source of the contamination. To a lesser extent, coverage focused on the political scandal caused by the false implication of Spanish farmers. Soon after government officials declared Egypt to be the source of the contamination, media coverage dropped off precipitously. Few media outlets pressured German authorities to answer for an investigation that they had previously criticized as "bumbling" (The Local 2011a) and an "embarrassment for one of the world's most advanced nations" (Der Spiegel 2011). One interviewee said, "It just sounds silly, but this outbreak was too small to really alter [regulations] in the EU." Another explained, "On a public level, people were satisfied when the source was identified and the disease was over. This was a one-day scandal."

The German policy response consisted of three modest reforms, which one federal official described to me as "doctoring around some minor points": (1) German authorities formalized the crisis council structure that they had created during the outbreak to coordinate across agencies; (2) disease reporting processes were modernized; and (3) in 2013, the EU adopted new production standards for sprouts, including a requirement to test regularly for $E$. coli. Given the lack of positive microbiological tests during the investigation, however, some of my interviewees doubted the efficacy of the new testing requirements. Furthermore, the policy response did little to reduce the risk of contamination and focused almost entirely on responding to contamination after the fact.

The paper proceeds as follows: First, it describes the theoretical foundation for a comparative study of national food risk regimes, drawing on previous research on organizational decision-making and comparative policy studies. Next, it explains the qualitative data and methods used to analyze U.S. and German regulatory regimes. The results are presented in three sections relating the range of policy options taken and ignored, social constructions of the outbreaks and associated food risks, and key differences in the structure and activities of each nation's food risk regime. The discussion explores the implications of these policy responses for contemporary food safety governance, arguing that failures to address the structural antecedents of foodborne disease outbreaks leave us vulnerable to future disasters.

\section{Food safety governance}

Risk management is a core responsibility of the modern state, which confronts new types of risks arising as an unintended byproduct of modernization (Beck 1992;
Giddens 1990). In the global "risk society" (Beck 1992), food-related threats have shifted from the pre-modern threats of adulteration and spoilage to modern microbial risks like E. coli and Listeria. The core irony of modern foodborne risks is that although the centralized, techno-scientific nature of the modern food system has dramatically reduced the frequency of bacterial contamination, these same organizational features increase the catastrophic potential of a single contamination event. This paradox exemplifies what organizational researchers call a "normal accident": when tightly coupled, complex systems inexorably result in catastrophic events (Perrow 1999, 2007; Stuart and Worosz 2013). In the global food system, modern manufacturing practices, industry concentration, and geographically dispersed supply chains have allowed foodborne pathogens to infect humans at a previously unprecedented scale. Microbial contaminants are not created by humans, but humans create the distribution systems that determine their catastrophic potential. Indeed, as food supply chains have become longer and more concentrated in recent decades, multi-state and multinational outbreaks have become more frequent (Nguyen et al. 2015).

Crises such as foodborne disease outbreaks can lead to important shifts in risk policy. Kingdon's (1997) multiplestreams model emphasizes that crises can serve as "focusing events" that trigger policy adaption when problems, policies, and politics intersect to create "policy windows." However, Birkland (1997, 2006, 2009) notes that natural and technological disasters tend to trigger policy changes only when they involve highly visible harms affecting large numbers of people and extensively organized policy communities. With policy domains involving limited public engagement, responses to disaster often focus on providing swift aid to victims rather than addressing the structural antecedents of disasters (Birkland 1997). Research on organizational decision-making also suggests that organizations often define and seek to resolve crises with solutions they already have in their collective repertoires, even if their "fit" with the crisis is questionable (Beamish 2002; Birkland 2006; Clarke 1991; Cohen et al. 1972). Organizations tend to pursue routinized solutions to crises unless the events trigger sufficient public attention or violate others' conceptions of legitimate action (Birkland 1997, 2006). In the U.S. and Germany, outbreaks have rarely prompted policy adaptation unless they involved obvious cases of institutional wrongdoing, such as the European BSE outbreak or the 1993 U.S. Jack in the Box outbreak. However, this literature fails to explain crossnational differences in policy responses to foodborne disease outbreaks when they do occur.

Comparative research reveals important cross-national differences in environmental and health policymaking 
(Brickman et al. 1985; Burri 2015; Daemmrich 2004; Jasper 1990; Vogel 2009, 2012). Previous research suggests that national differences in political cultures, economic and legal systems, and public expectations create contexts in which the same risks are assessed and managed differently (Jasanoff 2007). A common narrative, both in the academic literature and popular discourse, is that Europe tends to take a "precautionary" approach to risk management, whereas the U.S. focuses less on prevention and more on responding to documented evidence of harm (Brickman et al. 1985; Burri 2015). However, some scholars reject the notion that Europe is inherently more "precautionary," highlighting historical variations in regulatory stringency (Vogel 2012; Wiener and Rogers 2002).

Nevertheless, comparative research on national risk policies tends to focus almost entirely on emergent technological risks rather than risks that are less obviously the result of deliberate human action, such as microbial food contamination. Moreover, this literature often focuses on state regulation and excludes private governance schemes, even if many studies attend to the influence of non-state actors in policymaking. Consequently, the literature largely fails to account for several important dimensions of the outbreaks in this study, including the robust industry response to the U.S. outbreak and the lack of public dread and collective mobilization that often accompanies technological controversies in both regions. This paper aims to address these gaps by adopting food risk regimes as the focus of analysis; risk regulation regimes include the broad networks of public and private actors who assume responsibility for risk assessment and management in a particular policy domain (Ansell and Baur 2018; Hood et al. 2001). Contemporary food risk regimes are increasingly hybrid, involving the regulatory activities of state, industry, and third-party actors at national and often international scales (Lytton 2019b; Verbruggen and Havinga 2017). Following Hood et al. (2001), I trace how regime content (size, structure, and style) and context (risk type, public attitudes, and organized interests) shaped policy outcomes after the 2006 and 2011 outbreaks. Specific attention is paid to how each regime defined food risks and attempted to control them (Ansell and Baur 2018).

This research is sensitive not only to structural differences in national regimes, but also to the broader array of policy options that failed to gain traction in either case. The social dynamics underpinning the construction of some risks as non-problematic are just as instructive as the policymaking processes around collectively recognized problems. Freudenburg (2000) argued that analyzing this "nonproblematicity" is critical for understanding the factors that insulate institutions from reflexive scrutiny and hamper holistic reforms. Jones and Davidson (2014) adopted this approach in an investigation of the Canadian BSE crisis, demonstrating how dominant institutional arrangements prevented reflexive policy adaptation. Similarly, Stuart and Worosz (2012) found that U.S. responses to foodborne outbreaks often prioritize technical fixes over systemic reforms, arguing that anti-reflexivity protects capitalist production systems at the expense of consumer health and agricultural sustainability. This paper explores the potential for reflexive policy responses following two large-scale $E$. coli outbreaks. The analysis demonstrates that "non-problemicity" is a useful analytic lens for understanding both cases; agricultural practices were a non-problem in the German case, and U.S. actors failed to consider important structural vulnerabilities when development new agricultural controls. My goal is not to disparage the actions or intentions of U.S. or German risk managers, who worked diligently to protect consumer health after the outbreaks. Rather, by comparing institutional responses across national regimes and counterfactual outcomes, I seek to emphasize that policy responses are historically contingent and thereby broaden our collective imagination around policy possibilities.

\section{Data and method}

This analysis draws on three streams of data: (1) in-depth interviews with 36 participants in the U.S. and Germany; (2) over 300 English-language newspaper articles about the two outbreaks; and (3) over 250 additional archival documents.

Between May 2015 and July 2016, I conducted in-depth interviews with participants selected from the following groups: (1) federal and local government officials, (2) members of the food industry, (3) scientists and medical experts, and (4) consumer advocacy organizations. Participants were recruited from the list of people mentioned or quoted in the sample of newspaper articles about the outbreaks, and a "snowball" sampling strategy was used to identify additional participants. In total, I interviewed 23 participants in the U.S. and 13 in Germany. Interviews were semi-structured and lasted approximately 1-2 hours. Most interviews were conducted in person, though a few were conducted over the phone, and all interviews were recorded and transcribed. Although the content of the interviews varied, interviews generally focused on respondents' memories of the outbreak events and policy responses and their broader reflections on the longer-term impacts of the outbreak. This project was approved by the university institutional review board, and all participants consented to be interviewed.

The sample of newspaper articles was retrieved via the LexisNexis news service from the three largest, national English-language newspapers at the time of each outbreak, plus 1-2 additional newspapers of particular relevance to each outbreak. In the U.S. case, I analyzed articles about the outbreaks in the New York Times, USA Today, The Washington Post, and the San Jose Mercury News (located 
Table 1 Five alternative policy options

\begin{tabular}{ll}
\hline Policy options & Example actions \\
\hline 1. Consolidate food safety authority & Centralize authority over standard-setting and enforcement in a single agency \\
2. Abandon risky food products & Substitute less-risky products for bagged greens and raw sprouts \\
3. Reduce scale or speed of production & Hand-harvest leafy greens; decentralize processing; lower sprouting temperatures \\
4. Regulate cattle & Treat manure; increase distance between feedlots and produce fields; cull "super- \\
& shedder" cattle \\
5. Do nothing & N/A \\
\hline
\end{tabular}

in the Salinas Valley and chosen for its strong local coverage of the 2006 outbreak). In the German case, I analyzed news stories in Der Spiegel, Deutsche Welle, The Local, The Guardian (chosen for its European coverage), and El Pais (a Spanish newspaper chosen to capture the Spanish cucumber controversy). The search yielded 166 stories about the U.S. outbreak (from September 2006 to January 2013) and 135 articles about the German outbreak (from May to October 2011).

The remaining archival documents were provided by interviewees or collected via web searches. These documents included all official reports related to the outbreaks, press releases, public education materials, legal documents, blogs, public interviews with stakeholders, and academic articles. Most documents were originally written in English, and a few German-language reports were professionally translated into English.

Interview transcripts and archival documents were coded and analyzed inductively. The coding scheme was developed after an initial reading of the documents and refined in successive rounds of coding. Excerpts were analyzed in an iterative process that involved drafting analytic memos and data matrices to identify emerging themes, generate comparisons across cases, and verify findings (Emerson et al. 2011; Miles et al. 2013). Analyzing such a broad range of data facilitates the triangulation of findings across multiple sources. Moreover, the timing of the interviews several years after the outbreaks allowed me to analyze contemporaneous accounts of the events (found in archival documents) against respondents' memories of them. Archival documents were helpful in recovering the detailed chronology of events, while the interviews clarified what the outbreaks came to signify for different stakeholders over time.

The analysis focuses on two dimensions of the outbreaks that helped shape the divergent policy outcomes: (1) social constructions of the crisis as primarily an agricultural or health issue, involving an internal or external threat; and (2) institutionalized relations among state, industry, and public actors in each nation, which I collectively refer to as their "food risk regimes." Before examining these themes in detail, I first contextualize the policy outcomes within a broader range of alternative responses.

\section{Results}

\section{Policy options taken and ignored}

U.S. and German risk managers were confronted with similar risks during the 2006 and 2011 outbreaks, yet they pursued different policy responses: industry-led agricultural controls in the U.S. and modest state reforms in Germany. The benefit of hindsight often makes historical events seem inevitable, but the outcomes of the 2006 and 2011 outbreaks were not guaranteed. Below I review five alternative outcomes (summarized in Table 1), some of which might have offered equal or superior improvements to public health but were never considered seriously by stakeholders. My goal is not to criticize risk managers in either nation but rather to provide readers with a broader context of available options that can clarify the social dynamics that elevated certain options over the alternatives.

One potential response would be to consolidate government authority over food safety. Both the U.S. and German governments have faced decades of criticism for their fragmented authority over food safety, which is divided horizontally across agricultural and health agencies and vertically across federal, state, and local agencies (U.S. Government Accountability Office 1970, 1999; von Wedel 2001). Many interviewees agreed that government fragmentation is a major impediment to their work, yet stakeholders in neither nation attempted to consolidate food safety authority after the outbreaks. Interviewees were universally pessimistic about the possibility of restructuring regulatory authority, given that federalism is enshrined in both nations' constitutions and that disruptions to the current regime would be contentious, costly, and time-consuming. In Germany, for example, interviewees described federalism as a "sacred cow"; in the U.S., a federal official told me that the public health system is so fragmented, "it is amazing that it works at all." Nevertheless, interviewees felt like they had to make the best of a flawed system.

A second potential response would involve reexamining the food products associated with the outbreak, in this case bagged leafy greens (U.S.) and sprouts (Germany). Bagged greens are a recent invention, becoming a household staple 
only after technological advancements in the 1990s made it possible to produce them at scale (Stuart 2011). Although consumers love the convenience of bagged greens, these products carry a greater risk of contamination than whole or bunched greens due to differences in harvesting, centralized processing, and the sealed bags that create a hospitable environment for bacterial growth whenever the "cold chain" is broken. Despite these risks, no one seriously considered abandoning the bagged salad in the aftermath of the outbreak. One interviewee complained, "It's not a safe product for so many reasons, but people want convenience. What's unfortunate is that they don't understand that that convenience comes with more risk." Consumer fondness for bagged greens can be inferred from consumption trends during and after the outbreak: sales of bagged spinach dropped precipitously, but overall sales of bagged greens declined only slightly and then rebounded as consumers substituted other greens for spinach (Arnade et al. 2009).

Raw sprouts are even riskier than bagged greens, yet the idea of giving them up was similarly ignored in Germany. The warm, humid conditions required for sprouting are ideal for rapid bacterial growth, such that sprouting can amplify even small levels of pathogens. Many interviewees admitted privately that they avoid eating sprouts because of their heightened risk of contamination; "I love sprouts, but I won't eat them," said one respondent. However, sprouts consumption continued post-outbreak, and government officials, who reported in interviews that they feared getting sued for "communicating too much" about the risks of consuming sprouts, issued only a mild warning that people with "weak immune systems" might avoid eating sprouts (BfR 2011). One scientist said, "I don't think anything has changed. Sprouts are still served. They are still perceived as a healthy food."

A third potential response would be to reexamine the production practices that make bagged leafy greens and sprouts so risky. For example, hand-harvesting leafy greens allows for easier visual identification of contamination relative to mechanical harvesters, and processing greens in smaller batches reduces the spread of contaminants. Although U.S. manufacturers have implemented numerous technical strategies to manage pathogenic risks, there has been no serious consideration of adjustments that might challenge the current scale or pace of production (Stuart 2011; Stuart and Worosz 2012). With sprouts, research suggests that several practices may kill or slow the growth of pathogenic bacteria, including chlorine washes and lower sprouting temperatures (Fu et al. 2008; U.S. FDA 1999). However, European producers and consumers have actively resisted the use of chlorine on food (in contrast to the U.S.), and lower sprouting temperatures threaten profitability by lengthening production times and requiring more water and energy. The EU regulations developed after the 2011 outbreak do not contain requirements, or even suggestions, for specific preventative controls. They merely require member states to verify that sprout operators maintain clean facilities, use clean water, and regularly test sprouts and water for microbial contaminants. Several interviewees recognized the lack of policy specificity as a missed opportunity; for example, one interviewee said, "I think the learnings taken out of that outbreak are much poorer than they should have been."

A fourth policy alternative would be to regulate cattle, the primary animal reservoir of pathogenic E. coli. Pathogenic E. coli pass from cattle to humans via the "fecal-oral" route, when humans consume food or water contaminated with cattle feces. Cattle feedlots can produce millions of tons of untreated manure each year, making them a major vector for $E$. coli transmission via manure runoff that contaminates soil, air, and waterways, or is tracked through nearby fields by wildlife (Ali 2004). Although U.S. investigators traced the 2006 outbreak strain to a nearby cattle feedlot, there was little discussion about regulating feedlots after the outbreak. Stakeholders could have mandated treatment of cattle manure, established minimum distances between feedlots and agricultural fields, implemented stricter controls on manure runoff, or incentivized culling of infected cattle (given research suggesting that a small percent of cattle, as little as 2\%, are E. coli "super-shedders") (Arthur et al. 2013; Matthews et al. 2006). However, none of these options were seriously considered, much to the irritation of produce growers who felt unfairly burdened with another industry's problem. As one grower said, "The evidence is pretty clear that animal confinement operations are a big source of these pathogens, but no one is pointing a finger in that direction. It's really frustrating." German and European stakeholders similarly avoided regulating cattle in the aftermath of the 2011 outbreak, though the link to cattle was less clear in this case. As in the U.S., ruminants are the primary reservoir for $E$. coli infections in Europe, but evidence suggests that the rare strain implicated in the 2011 outbreak might have a human, not ruminant, reservoir (Beutin and Martin 2012; Karch et al. 2012). The origins and transmission pathway of the 2011 outbreak strain raise important questions for public health, underscoring the lesson that infectious diseases are constantly evolving and that mitigation efforts must be correspondingly adaptive.

A final option would be to do nothing. This might seem like an implausible response to a major public health crisis, but it is worth noting that the U.S. leafy greens industry had already pursued this strategy during the dozens of outbreaks prior to the 2006 outbreak (Powell and Chapman 2018; Turner et al. 2019). This strategy proved untenable during the 2006 outbreak because the U.S. spinach market evaporated after the FDA's consumer advisory, forcing industry players into a collective financial crisis. With no market for fresh spinach and increasing safety demands from buyers, "the industry pretty quickly got it through 
their heads that they had to do something significant," as one grower explained. In Germany, critics sometimes argue that "doing nothing" is precisely the strategy taken after the 2011 outbreak, but this is not quite accurate: federal agencies implemented some minor improvements to organizational procedures following the outbreak, and the EU established new standards for sprouts producers. However, it is important to note that in contrast to the U.S. response, the German response was oriented more toward improving responses to future outbreaks rather than preventing them. One interviewee noted that although previous crises like the BSE crisis "showed very severe problems with state audits of food and nutrition and problems with federalism, that was not the issue with EHEC. The problem with this scandal was that it took so long to identify the source."

By reviewing several plausible alternative responses to the outbreaks in question, we can appreciate that the outcomes were neither inevitable nor necessarily superior to the alternatives. Indeed, some of these alternatives would have addressed systematic vulnerabilities in the food system that were largely ignored by U.S. and German risk managers, which raises the question of how stakeholders came to pursue the observed responses. Below I present two themes that emerged in the analysis that help explain the policy responses: social constructions of the outbreaks and organizational dynamics among state, industry, and public actors.

\section{Social constructions of the outbreaks}

In interviews, regulators and industry representatives in both nations reported that the 2006 and 2011 outbreaks were the events that "woke them up" to the risks of fresh produce. Nevertheless, these events came to be understood in qualitatively different terms: U.S. stakeholders understood the outbreak primarily as a problem with the way fresh produce is produced, whereas German stakeholders understood the outbreak as a problem with outbreak response. Food safety spans the professional domains of agricultural and health experts, and both fields are necessarily engaged in food safety governance in both nations; even so, greater emphasis can be placed on one or the other domain in policy discourses. In the 2006 and 2011 outbreaks, this difference in framing helped shape policy responses: U.S. stakeholders created an industry-led program for farm-level food safety management, whereas German stakeholders sought to improve inter-organizational coordination during outbreak investigations.

Another key dimension of the social construction of these outbreaks is related to whether they were understood to involve internal versus external threats. The U.S. outbreak was quickly traced to California-grown spinach, and the fresh-cut spinach market collapsed soon after the FDA warned consumers to avoid eating fresh spinach in
mid-September 2006. These events forced spinach producers to recognize the outbreak as an internal threat to their financial viability and spurred them to collective action. One grower explained that at the time, he and others were "desperately trying to figure out a way to at least impress upon the regulators that we can restart this industry safely." It is important to note that although industry groups were motivated to address the financial threat of contaminated spinach, they did not necessarily acknowledge personal responsibility; as previously noted, regulatory proposals focused on farm-level controls despite evidence of failures at the processing facility, and blaming "nature" enabled stakeholders to pursue targeted technical fixes rather than structural reforms (Olimpi et al. 2019; Stuart 2011).

In contrast, German officials blamed the 2011 outbreak on actors external to the EU, in Egypt, which reduced political pressures for reform (BfR 2012). Although the implicated seeds were imported from Egypt, doubts remain about where the seeds were contaminated (Beutin and Martin 2012; Knödler et al. 2016), and sprouting facilities represent an important intervention opportunity regardless of whether the contamination occurred outside Europe. The official conclusion blaming Egypt for the contaminated seeds meant that decision-makers could halt Egyptian imports and claim that the threat had been neutralized. One microbiologist said, "Politically, it was great. You had somebody outside the European Union responsible for it." Others criticized the response, including a consumer advocate who said, "I always think this government lost the opportunity to really do better in the future, because they had that solution of Egypt, which is cheaper than saying, 'look, we have to reset the system." Social construction of the crises as involving internal or external threats shaped the subsequent response; internal threats require greater internal evaluation, a more disruptive process than blaming an outsider who can simply be expelled from the market.

Social constructions of the problem as primarily agricultural or health-related, and stemming from either an internal or external threat, therefore oriented stakeholders toward a preventative policy response in the U.S. and a reactive response in Germany. German interviewees viewed the 2011 outbreak as an unfortunate crisis that demanded a quick public health response but failed to reveal systemic vulnerabilities in food supply chains. Microbial contamination was viewed as an unfortunate inevitability: as more than one interviewee remarked, "these things happen." Interviewees focused on the public health response and largely agreed that aside from a few minor mistakes (most notably the Spanish cucumber announcement), the organizational response was appropriate. For example, a Hamburg official said, "If this EHEC outbreak was a catastrophe for everyone, maybe we would have had to change the [regulatory] structure. Maybe.” A federal epidemiologist expressed a 
Table 2 Food risk regimes in the United States and Germany (with differences in italics)

\begin{tabular}{|c|c|c|}
\hline & United States & Germany \\
\hline \multicolumn{3}{|l|}{ Regime content } \\
\hline Size & Large regulatory investment from state and industry & Large regulatory investment from state and industry \\
\hline Structure & $\begin{array}{l}\text { Agriculture and public health jointly regulated by federal } \\
\text { and state agencies } \\
\text { Federal agricultural authority divided by food type (meat/ } \\
\text { dairy vs. everything else) } \\
\text { Regulations harmonized at federal level }\end{array}$ & $\begin{array}{l}\text { Agriculture and public health jointly regulated by federal } \\
\text { and state agencies } \\
\text { Federal agricultural authority divided by function (risk } \\
\text { assessment vs. management) } \\
\text { Regulations harmonized at EU level }\end{array}$ \\
\hline Style & $\begin{array}{l}\text { Regulators value inter-agency cooperation } \\
\text { Disease surveillance involves molecular subtyping and/or } \\
\text { whole genome sequencing }\end{array}$ & $\begin{array}{l}\text { Regulators value protecting science from politics } \\
\text { Disease surveillance involves case reports; subtyping less } \\
\text { common }\end{array}$ \\
\hline \multicolumn{3}{|l|}{ Regime context } \\
\hline Risk type & $\begin{array}{l}\text { Pathogens on fresh produce are difficult for consumers to } \\
\text { detect or avoid }\end{array}$ & $\begin{array}{l}\text { Pathogens on fresh produce are difficult for consumers to } \\
\text { detect or avoid }\end{array}$ \\
\hline Public attitudes & $\begin{array}{l}\text { Moderate concern about microbial food safety yet limited } \\
\text { mobilization }\end{array}$ & $\begin{array}{l}\text { Moderate concern about microbial food safety yet limited } \\
\text { mobilization }\end{array}$ \\
\hline Organized interests & $\begin{array}{l}\text { Implicated industry is large and highly concentrated } \\
\text { Industry actors have close ties with regulators }\end{array}$ & $\begin{array}{l}\text { Implicated industry is smaller and decentralized } \\
\text { Ties between industry and regulators have weakened over } \\
\text { time }\end{array}$ \\
\hline
\end{tabular}

similar sentiment, saying, "If this had been a disaster-it was a disaster for all the people affected-but the way it was managed, I think, wasn't a disaster." Conversely, U.S. stakeholders did not accept microbial contamination as a sad inevitability but rather viewed it as a problem ripe for intervention. Industry representatives expressed confidence in their ability to identify technical solutions to pathogenic contamination on produce, and industry players banded together to fund basic research on food safety through the newly established Center for Produce Safety at the University of California, Davis. As one grower explained, "It was a defining moment for the industry, no doubt about it. And for a good reason. This is the same food that I take home and put on the table for my family and it's the same food our employees take home, so it's got to be safe." No one I interviewed believed that it will ever be possible to eliminate foodborne risks, but U.S. stakeholders expressed greater resolve than their German counterparts to achieve significant risk reductions.

\section{Divergent national food risk regimes}

The institutionalized relations among key stakeholder groups-including government regulators, the food industry, and public organizations-emerged as a key theme in interviews, with respondents frequently pointing to longstanding organizational dynamics to explain policy outcomes. I use the concept of national food risk regimes to describe the networks of public and private actors that govern food safety in different national contexts, encapsulating the balance of power across these actors, institutionalized relations among them, and collective values that shape their activities (Hood et al. 2001). Food risk regimes emerge from ongoing negotiations among state, industry, and thirdparty organizations, and they fluctuate over time in response to food-related crises. Nevertheless, certain dimensions of U.S. and German food risk regimes achieved relative stability by the end of the twentieth century and laid the groundwork for the responses to the 2006 and 2011 outbreaks.

The paragraphs below illustrate how the organizational dynamics of national food risk regimes interacted with social constructions of the outbreaks to produce policy outcomes. Table 2 summarizes key dimensions of each food risk regime that emerged inductively from the data, organized by Hood et al. (2001) framework for regulatory regime content (size, structure, and style) and context (risk type, public attitudes, and organized interests). The analysis begins with the state agencies tasked with governing food safety (regime content), then assesses their relations with industry actors and the public (regime context). Critically, many of these dynamics remain important components of U.S. and German food risk regimes, the implications of which are discussed in the final section.

\section{Government structures and relations in the U.S. and Germany}

Both the U.S. and Germany have federalist political systems, meaning that a central (federal) government shares authority with regional (state) governments. Agriculture and public health are jointly regulated by federal and state governments in both nations; legislation is generally passed at the federal level and implemented by states. States assume 
responsibility for food safety inspections, infectious disease surveillance, and outbreak investigations (unless state officials formally invite federal authorities to participate). U.S. and German food risk regimes therefore share important similarities, but significant differences remain in their structure and activities.

Horizontal and vertical divisions of power are similar across both nation's public health agencies, but the organization of national agricultural agencies differs. In the U.S., federal agricultural authority is divided across different types of foods: meat and dairy are regulated by the US Department of Agriculture (USDA), and all other foods are regulated by the FDA. Risk assessment and management are handled internally by both agencies. In contrast, German agencies are divided by function rather than product: German agencies were reorganized after the BSE crisis to impose strict divisions between the authorities responsible for risk assessment (Federal Institute for Risk Assessment, or BfR) and risk management (Federal Office of Consumer Protection and Food Safety, or BVL, and Federal Ministry for Food, Agriculture, and Consumer Protection, or BMELV). Both of these fragmented systems create regulatory challenges, but only the weaknesses of Germany's system became salient during the outbreaks under study. The U.S. system poses challenges especially for outbreaks involving multiingredient products and for regulatory parity across different types of products. ${ }^{3}$ However, the 2006 U.S. outbreak was quickly traced to a single commodity, so the FDA's authority over the investigation was never in dispute. In Germany, the division between risk assessment and risk management contributed to organizational frictions during the outbreak investigation; stakeholders on either side of the divide knew less about each other's work than would have been ideal for a swift and coordinated response, contributing to confusion about which food products were implicated in the outbreak. As one federal epidemiologist explained:

The difficult point is the separation between the human disease side and the food safety side. You have those two sides and then somewhat of a barrier between them, but then you have that times 16, basically. And actually, in a way, you have it times 400 because every health department that you work with is a bit different. That makes it so cumbersome, and I can never get over that it's so ineffective.

\footnotetext{
${ }^{3}$ For example, FDA and USDA take different approaches to regulating bacterial contamination. Food safety regulatory authority in the U.S. stems from 1906 legislation banning food adulteration, yet FDA and USDA disagree about whether microbial pathogens are "adulterants"; FDA views the presence of pathogens on food products as adulteration, whereas USDA does not view the presence of pathogens (other than E. coli 0157:H7) on raw meat as adulteration because pathogens should be killed with cooking (Thomas 2014).
}

The issue of multilevel governance also drives important differences in food risk regimes. Germany is a federalist nation embedded in another quasi-federalist political system: the European Union. Multilevel governance can weaken risk management when authority is divided in such a way that no officials or agencies can be held individually responsible for disasters, a phenomenon that Beck (1998, p. 18) calls "organized irresponsibility." National crises are often expected to yield national policy responses, yet the German federal government was in some ways the worst-positioned to make substantive reforms after the 2011 outbreak. Food safety regulations are established one level above (i.e., the EU) and implemented one level below (i.e., the Länder, or federal states). The federal level plays a coordinating role in the domain of food safety and has limited powers to impose new programs on federal states and municipalities. Given that the outbreak was widely framed not as a European problem but as a German problem, EU authorities felt no great pressure to pursue strong preventative measures, and German agencies lacked the authority to do so themselves. The net result was a system in which no level of governance contained officials who felt responsible for preventing the next outbreak. The muted policy response to the 2011 outbreak was therefore at least partially a result of "organized irresponsibility" among government agencies.

Beyond the formal structures of governance, the relations between agencies also play a significant role in shaping outbreak responses. U.S. food safety officials operate within a fragmented policy arena but have pursued programs and processes that foster regular inter-agency collaboration. Federal agencies often contract with state authorities to fulfill their regulatory responsibilities, and federal agencies also foster horizontal collaboration by placing representatives in each other's offices and convening regular meetings. Additionally, the sophisticated national disease surveillance network ensures that state and federal agents regularly communicate about emerging health threats. Although the process of reporting infectious diseases proceeds similarly in both nations, the U.S. system contains a stronger bureaucratic mandate to identify pathogen strains via molecular subtyping (or, increasingly, whole genome sequencing). The pathogen strain has no clinical significance, but it is critical for national disease surveillance. Molecular subtyping and whole genome sequencing allow U.S. authorities to identify outbreaks with greater precision and detect smaller and more geographically diffuse outbreaks. Moreover, because the U.S. surveillance system identifies emerging outbreaks with greater frequency, U.S. agencies collaborate more often on outbreak investigations. ${ }^{4}$ The result is a system in which

\footnotetext{
${ }^{4}$ Some might interpret fewer outbreaks to mean a safer food system, but the epidemiologists I interviewed were confident that many more outbreaks occur in Germany than are identified by national surveillance.
} 
officials have good working knowledge of the people and processes in other agencies and can draw on these relationships during crises. I do not mean to romanticize the social relations among U.S. risk managers; interviewees also described the types of turf battles and personality clashes present in most human organizations. However, compared to the strictly siloed German system, U.S. authorities demonstrated stronger commitments to inter-agency cooperation, and they cited these ties during interviews as being important for successful outbreak investigations. As one federal official said:

The system we have is not a system that anybody would ever design to do an outbreak investigation, but what we've been able to do is despite the organizational challenges, we've figured out a system so that we can work collaboratively together to solve outbreaks and do it relatively expeditiously. Part of it is setting up good laboratory-based systems, having good epidemiological approaches, and having good regulatory environmental health assessment, those three big pieces all happening at the same time and having dedicated partners and resources who can make the individual pieces happen and have them all put together.

In Germany, stricter divisions between the agencies involved in risk assessment and risk management, federal and state agencies, and public health and agricultural agencies have created a system in which officials largely pursue their own work without regular inter-agency collaboration. Korinek and Strassheim (2013) describe the German food safety governance regime as lacking "conceptual slack," since organizational boundaries prevent experts from different backgrounds from sharing their experiences and expertise. During the 2011 outbreak, German authorities failed to formally coordinate their activities until several weeks into the investigation, after officials in Hamburg mistakenly announced that Spanish cucumbers were the source of the contamination. Instead, state agencies conducted parallel, independent investigations, and some were reluctant to share their data with other state and federal authorities. This created delays and mistakes during the investigation that might have been avoided. Moreover, these failures likely reinforced the general impression that the "problem" represented by the outbreak was in the public health response, not in agriculture. German officials universally praised the EHEC Task Force they formed during the investigation; for example, one official said "it was one of the most important lessons we learned, that you have to bring these three levels [federal, state, and local] on a daily basis together." However, the culture of government silos was so strong that the task force was disbanded after 1 month, and no serious attempt was made to continue regular collaboration. Officials established a process for re-establishing the task force during national crises, but it has re-formed only once since then (during a 2012 norovirus outbreak). The interpersonal learning that occurred during the 2011 outbreak therefore failed to disrupt inter-agency dynamics. Given staff turnover in the years since the task force last met, it is likely that organizational lessons learned during previous crises will need to be relearned during the next crisis.

\section{Food industry actors in the U.S. and Germany}

The balance of power between state and industry actors varies cross-nationally and has also fluctuated over time. In the U.S., industry actors have exerted substantial power in the food policy arena over the previous half-century and have frequently succeeded in resisting the expansion of federal oversight (Thomas 2014). The "revolving door," whereby industry actors transition in and out of public office, also ensures that industry perspectives are well-represented in policymaking and enforcement. The outsized influence of the food industry in U.S. food safety governance helps explain why leafy greens growers were granted such latitude in determining the policy response to the 2006 E. coli outbreak. California regulators considered imposing mandatory regulations after the outbreak, but industry organizations convinced them to abandon their plans and allow industry leaders to pursue their own policy solution instead (Schmit 2007). In Germany, in contrast, the food industry's influence in policymaking has declined over the last half-century, especially after the BSE crisis prompted federal reorganization in the early 2000s. This helps explain why industry representatives were relatively absent from policy debates following the 2011 outbreak. EU regulators consulted members of industry during the development of the 2013 sprouts regulations, but it was never suggested that industry organizations could lead the reform efforts. Industry-state relations therefore constrained which responses to the outbreaks were considered legitimate.

It is also important to assess structural features of the implicated food industries to understand the direction of the policy responses. Although the 2006 U.S. and 2011 German outbreaks were traced to similar food products (i.e., fresh salad ingredients), these products came from vastly different industries. The U.S. leafy greens industry is a multi-billion dollar industry, with $83 \%$ of U.S. households consuming bagged leafy greens (Cook 2015). The industry is also highly concentrated, with four firms controlling almost $90 \%$ of the fresh-cut salad market in 2006 (Cohen 2008). In contrast, the European sprouts industry is small and decentralized, and it produces a product that many enjoy 
as a garnish but few would consider a staple. ${ }^{5}$ In 2011, the sprouts industry consisted of around 100 businesses scattered throughout the EU. European sprouts production was a EUR 200 million industry, with EUR 30 million (15\%) being produced in Germany (EFSA 2011).

Differences in the size and concentration of the implicated industries played a role in shaping policy responses to the two outbreaks. In the U.S., the leafy greens industry could mobilize relatively quickly by virtue of their vast resources, in-house expertise, and market concentration; with few players controlling most of the fresh-cut market, only a handful of firms had to endorse the Leafy Greens Marketing Agreement for it to ensure virtually industry-wide compliance. Moreover, several firms already had food safety specialists on staff (and others would follow suit), enabling industry actors to leverage their own scientific expertise in the bid to develop a legitimate policy response. In contrast, it is unlikely that the small, decentralized sprouts industry in Europe could have achieved a similar effort even if sprouts operators had been more coordinated. Few, if any, had the resources to hire scientists to develop and oversee internal food safety programs, let alone create an industry-wide program. ${ }^{6}$ Thus, the U.S. industry-led policy response required an implicated industry that was powerful and concentrated enough to manage the coordination costs of the LGMA. The German outbreak similarly involved massive economic losses for sprouts producers, but they lacked the power and coordination to launch a similar response.

\section{The absent public}

Public mobilization and accountability often shape institutional responses in other policy domains, yet microbial food safety garners little public engagement in either nation. ${ }^{7}$ This contrasts with spirited public responses to other food-related concerns, such as genetically modified foods, pesticides, and antibiotics. Few consumer organizations focus specifically

\footnotetext{
5 Epidemiologists consider sprouts to be a "stealth food" because they are often used as a garnish, and garnishes are commonly forgotten when people are asked to recount recent meals. This likely delayed the identification of sprouts as the outbreak vehicle in 2011.

${ }^{6}$ Sprouts growers came together after the outbreak to form the European Sprouted Seed Association (ESSA) and consult with EU agencies about the 2013 regulations, but their role during the policymaking process was mainly advisory.

${ }^{7}$ Reduced public mobilization on this issue remains to be explained, but it should not be interpreted as minimal concern; national surveys in both nations demonstrate that food safety is a significant concern for most consumers (European Commission 2010; U.S. FDA 2010). The explanation may be related to previous research showing that microbial food risks are viewed by consumers as more "natural" and personally controllable than technological or chemical food risks (Meagher 2019).
}

on the issue of microbial food safety, and those that do often focus more on consumer education and advocacy than on organizing grassroots campaigns. ${ }^{8}$ Risk managers also rarely engage in public outreach on food safety-related policymaking. In interviews, risk managers claimed to consider public expectations in selecting among policy options, but these comments usually reflected shared assumptions about public opinion rather than insights gleaned from direct engagement.

This commonality between U.S. and German food risk regimes cannot explain the observed policy divergence, but it does help explain why both national responses largely reinforced the institutional status quo. Food safety is a "policy without a public" in both nations (May 1991): an issue which fails to sustain much public conflict and for which relevant policy discussions tend to be dominated by technical experts outside of the public sphere. Risk managers in this domain are subject to less public accountability than risk managers in other policy domains, so they face reduced pressure to demonstrate broadscale reforms after crises (unless the crises involve obvious malfeasance). Greater public engagement after the 2006 and 2011 outbreaks might have strengthened food safety governance in both nations if regulators had felt pressure to pursue larger or more holistic reforms, including the solutions discussed above in "Policy options taken and ignored" section.

\section{Discussion}

This research drew on qualitative interviews, newspaper archives, and official records to trace how regulatory regimes in the U.S. and Germany responded so differently to the "new" threat of contaminated produce. My analysis of the 2006 and 2011 E. coli outbreaks reveals that despite important similarities in the material risks and national regulatory contexts, each outbreak was viewed in fundamentally different terms: the U.S. outbreak was understood primarily as an agricultural problem that led to an industry-led agricultural solution, whereas the German outbreak was understood as a human disease problem that did not spark substantial reforms once the acute health crisis passed. These contrasting responses can be traced to the interplay between social constructions of the outbreak and the organizational dynamics of food safety governance in each nation, including the balance of power across key stakeholders, patterned relations among them, and shared beliefs around cooperation and risk management. These differences resulted in different

\footnotetext{
${ }^{8}$ Consumer groups focusing on food safety include the Consumers Union, Center for Science in the Public Interest, and STOP Foodborne Illness in the U.S.; and the Federation of German Consumer Organizations (vzbv) and Stiftung Warentest in Germany.
} 
regulatory choices during and after the 2006 and 2011 outbreaks, and they remain relevant for contemporary debates about food safety governance.

When we consider the policy responses to the 2006 and 2011 outbreaks against a range of plausible responses that were never seriously considered, important differences between U.S. and German food risk regimes emerge: In the U.S., strong industry-state relations and a collective value for inter-agency cooperation allowed investigators to overcome structural barriers to coordination and see an industrycreated program as a legitimate solution to the long-standing problem of contaminated leafy greens. In Germany, regulatory fragmentation combined with a strong commitment to agency independence and a reactive orientation to microbial risks meant that the investigation faced numerous coordination challenges and resulted in few substantial reforms. In both nations, public mobilization failed to materialize after the outbreaks, reducing pressure for risk managers to consider regulatory options that might have threatened the institutional status quo.

Evaluating the impact of the 2006 and 2011 policy responses is complicated both by limited data on pathogen levels and illnesses and the fact that overlapping public and private regulatory schemes make it difficult to credit any outcomes to individual policy changes (Lytton 2019a). Nevertheless, my analysis reveals that both regimes failed to target structural causes of large-scale outbreaks and thus retained some systemic vulnerabilities. For example, substantial improvements to German food safety governance could be achieved by improving ongoing coordination across EU, federal and state agencies, expanding and modernizing national disease surveillance systems, and pursuing more stringent preventative controls for certain foods (like sprouts) that have an elevated risk of contamination. Recent EU regulatory reforms have sought to improve transparency in risk assessments (EU 2019/1381) and encourage food businesses to maintain a "food safety culture" (EU 2021/282), yet the challenges around inter-agency coordination, disease surveillance, and preventative controls remain unresolved. In the U.S., leafy greens have remained a common source of $E$. coli outbreaks since the establishment of the LGMA. Dozens of multi-state outbreaks have been traced to leafy greens in the last 10 years, including one in 2018 that matched the scale of the 2006 outbreak (Marshall et al. 2020). The LGMA adopted stricter requirements after the 2018 outbreak, including larger buffers between fields and cattle feedlots and bans on irrigation with untreated water (Latack and Ozeran 2020; Ward 2019). However, some criticized this response as "hasty" due to its thin scientific basis and failure to consider how stricter technocratic controls can intensify pathogenic risks (Latack and Ozeran 2020; Baur 2021). The supply chain consolidation that enables largescale contamination remains a "non-problem" for the private and public regulations governing U.S. leafy greens, including the LGMA and the 2011 Food Safety Modernization Act. Important systemic vulnerabilities remain in both the U.S. and German food risk regimes.

Addressing these systemic vulnerabilities will require better data and thoughtful regulatory reforms. Many food safety controls are based on limited scientific evidence, and practitioners often struggle to assess the effectiveness of specific interventions (Lytton 2019a). Better data on how specific production practices and mitigation strategies impact pathogen levels would enable regulatory regimes to make targeted interventions, reduce "audit fatigue" for food producers, and avoid costly requirements that amount to little more than "food safety theater." Stronger commitments to disease surveillance and product traceability could also enhance our ability to learn from outbreaks about the sources and spread of food contamination. Outbreak investigations often reveal important information about emerging pathogens and transmission pathways, yet most outbreaks are never solved due to limited data and resources (Fischer et al. 2015). Greater investment in the infrastructure of outbreak investigations might produce valuable insights about which policy reforms should be prioritized. Encouraging public engagement within U.S. and German food risk regimes might also drive policy improvements; public deliberation could help challenge the "anti-reflexive" tendencies of technocratic governance regimes by exposing the normative choices embedded in food policy debates (Stuart and Worosz 2012).

One goal with this research has been to demonstrate the value of cross-national, comparative analysis for understanding the cultural and organizational dynamics that contribute to policy outcomes. These cases reveal experts and practitioners whose goals were nearly universal (i.e., to reduce the incidence of foodborne illness) but whose conceptions of the problem and subsequent actions were shaped by social processes that differ across regulatory regimes. This analysis is rooted in two national contexts, the U.S. and Germany, but the findings draw attention to organizational dynamics that are likely relevant to other regions. Every modern food risk regime involves actors from local and national government, industry, public health and medicine, and this analysis suggests that greater attention to the structure of these networks and relations among actors may yield important insights about policy outcomes. The absence of public mobilization was important for explaining the direction of the policy responses in these cases, yet other regions or crises might involve greater public visibility, which would be important to assess.

I have also argued that understanding institutional responses to foodborne outbreaks requires widening the analytical lens to include policy options not taken, or what Freudenburg (2000) called the construction of "non-problematicity." As Jones and Davidson (2014) have argued, "exploring the construction of non-problems and identifying what is absent from dialogues 
about food safety...introduces the opportunity for imagining alternatives." Future research on non-problematicity in food systems governance should critically evaluate how food safety problems are framed by various actors and note the presence or absence of key stakeholders in decision-making. It should also be attentive to state and industry resistance toward policy interventions that might greatly reduce the spread of pathogenic contamination. For example, decentralizing food production could dramatically reduce the frequency of foodborne outbreaks, yet it rarely enters the discourse around outbreak prevention. Foodborne outbreaks emerge from complex, consolidated food systems, yet policy solutions often target individual actors (through audits and controls) without addressing the social and ecological systems that amplify risks and reduce resilience (Baur 2021; Stuart 2011). Future work could also interrogate the extent to which policy responses target the original point of contamination versus the points with the greatest potential to mitigate harm. Contamination is inevitable in agricultural fields, but regulatory regimes might prevent more illnesses by targeting downstream opportunities for cross-contamination (e.g., processing and packaging) rather than intensifying efforts to sterilize fields-especially given evidence that sterilization efforts can backfire (Karp et al. 2015; Olimpi et al. 2019). Understanding and improving policy responses to outbreaks requires taking a broad view not only of the systems that create and amplify food risks, but also of the networks of actors that actively construct problem definitions and policy solutions after crises.

Acknowledgements I am grateful to Tom Beamish, Nicole Woolsey Biggart, Xiaoling Shu, Zeke Baker, Joanna Hale, Angela Kranz, Caitlin Daniel, and members of the UCD Food Systems Discussion Group for advice and feedback at multiple stages of this project. I also wish to thank the following research assistants for helping me collect and analyze archival materials: Jason Boykin, Jaskiran "Jassy" Grewal, Mohammad Reza Shirmast, Yuma Sakakura, and Katherine Shuai.

Funding Funding was provided by University of California, Davis and P.E.O. International.

Open Access This article is licensed under a Creative Commons Attribution 4.0 International License, which permits use, sharing, adaptation, distribution and reproduction in any medium or format, as long as you give appropriate credit to the original author(s) and the source, provide a link to the Creative Commons licence, and indicate if changes were made. The images or other third party material in this article are included in the article's Creative Commons licence, unless indicated otherwise in a credit line to the material. If material is not included in the article's Creative Commons licence and your intended use is not permitted by statutory regulation or exceeds the permitted use, you will need to obtain permission directly from the copyright holder. To view a copy of this licence, visit http://creativecommons.org/licenses/by/4.0/.

\section{References}

Ali, S. Harris. 2004. A socio-ecological autopsy of the E. coli O157:H7 Outbreak in Walkerton, Ontario, Canada. Social Science \& Medicine 58 (12): 2601-2612.

Ansell, Christopher, and Patrick Baur. 2018. Explaining trends in risk governance: How problem definitions underpin risk regimes. Risk, Hazards \& Crisis in Public Policy 9 (4): 397-430.

Arnade, Carlos, Linda Calvin, and Fred Kuchler. 2009. Consumer response to a food safety shock: The 2006 food-borne illness outbreak of E. coli O157:H7 linked to spinach. Applied Economic Perspectives and Policy 31 (4): 734-750.

Arthur, Terrance M., Rafiq Ahmed, Margo Chase-Topping, Norasak Kalchayanand, John W. Schmidt, and James L. Bono. 2013. Characterization of Escherichia coli O157:H7 strains isolated from supershedding cattle. Applied and Environmental Microbiology 79 (14): 4294-4303.

Baur, Patrick F. 2021. Missing the outbreak for the germs: Institutionalized non-knowledge and industrial power in agrofood safety governance. Elementa: Science of the Anthropocene 9 (1): 00041.

Beamish, Thomas D. 2002. Waiting for crisis: Regulatory inaction and ineptitude and the Guadalupe Dunes oil spill. Social Problems 49 (2): $150-177$.

Beck, Ulrich. 1992. Risk society: Towards a new modernity. Beverly Hills, CA: Sage Publications.

Beck, Ulrich. 1998. Politics of risk society. In The politics of risk society, ed. J. Franklin, 9-22. Cambridge, UK: Polity Press.

Beutin, Lothar, and Annett Martin. 2012. Outbreak of Shiga toxin-producing Escherichia coli (STEC) O104:H4 infection in Germany causes a paradigm shift with regard to human pathogenicity of STEC strains. Journal of Food Protection 75 (2): 408-418.

BfR. 2011. EHEC outbreak 2011: Recommendations on the handling of sprouts. http://web.archive.org/web/20170712072212/http:// www.bfr.bund.de/en/press_information/2011/41/ehec_outbreak_ 2011_recommendations_on_the_handling_of_sprouts- 127982 . html. Accessed 9 March 2019.

BfR. 2012. EHEC outbreak 2011: Investigation of the outbreak along the food chain. http://web.archive.org/web/20170818221623/ http://www.bfr.bund.de/cm/350/ehec-outbreak-2011-investigat ion-of-the-outbreak-along-the-food-chain.pdf. Accessed 3 March 2019.

Birkland, Thomas A. 1997. After disaster: Agenda setting, public policy, and focusing events. Washington, D.C.: Georgetown University Press.

Birkland, Thomas A. 2006. Lessons of disaster: Policy change after catastrophic events. Washington, D.C.: Georgetown University Press.

Birkland, Thomas A. 2009. Disasters, lessons learned, and fantasy documents. Journal of Contingencies and Crisis Management 17 (3): 146-156.

Brickman, Ronald, Sheila Jasanoff, and Thomas Ilgen. 1985. Controlling chemicals: The politics of regulation in Europe and the United States. Ithaca, NY: Cornell University Press.

Burri, Regula Valérie. 2015. Imaginaries of science and society: Framing nanotechnology governance in Germany and the United States. In Dreamscapes of modernity: Sociotechnical imaginaries and the fabrication of power, ed. S. Jasanoff and S.-H. Kim, 233-253. Chicago, IL: University of Chicago Press.

California Food Emergency Response Team (CalFERT). 2007. Investigation of an Escherichia coli O157:H7 outbreak associated with Dole pre-packaged spinach. Sacramento, CA: California Department of Health Services and the U.S. Food and Drug Administration. 
Calvin, Linda. 2007. Outbreak linked to spinach forces reassessment of food safety practices. Amber Waves. http://web.archive.org/web/ 20190310063713/https://www.ers.usda.gov/amber-waves/2007/ june/outbreak-linked-to-spinach-forces-reassessment-of-foodsafety-practices/. Accessed 9 March 2019.

CDC. 2006a. Health alert: Multiple states investigating a large outbreak of E. Coli O157:H7 infections. https://web.archive.org/ web/20201007193807/https://stacks.cdc.gov/view/cdc/25160. Accessed 7 October 2020.

CDC. 2006b. Multistate outbreak of E. Coli 0157:H7 infections linked to fresh spinach (final update). https://web.archive.org/ web/20200924051039/https://www.cdc.gov/ecoli/2006/spina ch-10-2006.html. Accessed 7 October 2020.

Clarke, Lee. 1991. Acceptable risk?: Making decisions in a toxic environment. Berkeley, California: University of California Press.

Cohen, Daniel. 2008. The history, politics \& perils of the current food safety controversy: CAFF guide to proposed food safety regulations. Davis, California: Community Alliance with Family Farms.

Cohen, Michael D., James G. March, and Johan P. Olsen. 1972. A garbage can model of organizational choice. Administrative Science Quarterly 17 (1): 1-25.

Cook, Roberta. 2015. Trends in the marketing of fresh produce and fresh-cut/value-added produce. http://web.archive.org/web/20190 310064814/https://arefiles.ucdavis.edu/uploads/filer_public/95/ 83/9583470c-cec3-42bf-8718-a8d2930a6525/freshcut2015upd ate150501.pdf. Accessed 9 March 2019.

Daemmrich, Arthur A. 2004. Pharmacopolitics: Drug regulation in the United States and Germany. Chapel Hill, NC: University of North Carolina Press.

DeLind, Laura B., and Philip H. Howard. 2008. Safe at any scale? Food scares, food regulation, and scaled alternatives. Agriculture and Human Values 25 (3): 301-317.

Department of Health and Human Services (DHHS) Office of the Inspector General. 2010. FDA inspections of domestic food facilities. http://web.archive.org/web/2019031006 5053/https://oig.hhs. gov/oei/reports/oei-02-08-00080.pdf. Accessed 9 March 2019.

Der Spiegel. 2011. Berlin blasted for E. coli crisis management: EU wants Germany to seek international help. June 8.

EFSA. 2011. Technical hearing with Freshfel Europe on the draft scientific opinion: The risk posed by Shiga toxin producing Escherichia coli (STEC) and other pathogenic bacteria in seeds and sprouted seeds. EFSA Supporting Publications 9 (11): 203.

Emerson, Robert M., Rachel I. Fretz, and Linda L. Shaw. 2011. Writing ethnographic fieldnotes, 2nd ed. Chicago: University of Chicago Press.

European Commission. 2010. Eurobarometer 73.5: Civil justice, development aid, Africa and the European Union, and food risk.

Fischer, Nils, Ariel Bourne, and David Plunkett. 2015. Outbreak alert! 2015. Washington, D.C.: Center for Science in the Public Interest.

Freudenburg, William R. 2000. Social constructions and social constrictions: Toward analyzing the social construction of 'the naturalized' as well as 'the natural'. In Environment and global modernity, ed. G. Spaargaren, A. Mol, and F. Buttel, 103-119. Thousand Oaks, CA: SAGE Publications.

Fu, Tong-Jen., Karl F. Reineke, Stuart Chirtel, and Olif M. Vanpelt. 2008. Factors influencing the growth of Salmonella during sprouting of naturally contaminated alfalfa seeds. Journal of Food Protection 71 (5): 888-896.

Giddens, Anthony. 1990. The consequences of modernity. Stanford, CA: Stanford University Press.

Hood, Christopher, Henry Rothstein, and Robert Baldwin. 2001. The government of risk: Understanding risk regulation regimes. Oxford, UK: Oxford University Press.

International Fresh-Cut Produce Association, Produce Marketing Association, United Fresh Fruit and Vegetable Association, and
Western Growers Association. 2006. Commodity specific food safety guidelines for the lettuce and leafy greens supply chain. http://web.archive.org/web/20190310070723/https://www.fda. gov/downloads/Food/GuidanceRegulation/UCM169008.pdf. Accessed 9 March 2019.

Jasanoff, Sheila. 2007. Designs on nature: Science and democracy in Europe and the United States. Princeton, N.J.: Princeton University Press.

Jasper, James M. 1990. Nuclear politics: Energy and the state in the United States, Sweden, and France. Princeton, N.J.: Princeton University Press.

Jones, Kevin Edson, and Debra J. Davidson. 2014. Adapting to food safety crises: Interpreting success and failure in the Canadian response to BSE. Food Policy 49: 250-258.

Karch, Helge, et al. 2012. The enemy within us: Lessons from the 2011 European Escherichia coli O104:H4 outbreak. EMBO Molecular Medicine 4 (9): 841-848.

Karp, Daniel S., Patrick Baur, Edward R. Atwill, Kathryn De Master, Sasha Gennet, Alastair Iles, Joanna L. Nelson, Amber R. Sciligo, and Claire Kremen. 2015. The unintended ecological and social impacts of food safety regulations in California's central coast region. BioScience 65 (12): 1173-1183.

Kingdon, John W. 1997. Agendas, alternatives, and public policies, 2nd ed. New York, NY: HarperCollins Publishers.

Knödler, Michael, Michael Berger, and Ulrich Dobrindt. 2016. Longterm survival of the Shiga toxin-producing Escherichia coli O104:H4 outbreak strain on fenugreek seeds. Food Microbiology 59: 190-195.

Korinek, Rebecca Lea and Holger Strassheim. 2013. Multilevel coordination in crisis: The case of EHEC. In Annual Conference of the Policy Analysis and Public Administration Working Group of the $D V P W$. Bamberg, Germany.

Latack, B., and R. Ozeran. 2020. Hasty responses to foodborne illness outbreaks impact California growers. California Agriculture 74 (1): 4-10.

Lytton, Timothy D. 2019a. Outbreak: Foodborne illness and the struggle for food safety. Chicago, IL: University of Chicago Press.

Lytton, Timothy D. 2019b. Technical standards in health \& safety regulation: Risk regimes, the new administrative law, and food safety governance. In Cambridge handbook of technical standardization law, vol. 2: Administrative law, copyright, trademark, and international law, ed. J.L. Contreras. Cambridge, UK: Cambridge University Press.

Marshall, Katherine E., April Hexemer, Sharon L. Seelman, Marianne K. Fatica, Tyann Blessington, Maha Hajmeer, Hannah Kisselburgh, Robin Atkinson, Kristin Hill, Davendra Sharma, Michael Needham, Vi. Peralta, Jeffrey Higa, Karen Blickenstaff, Ian T. Williams, Michael A. Jhung, Matthew Wise, and Laura Gieraltowski. 2020. Lessons learned from a decade of investigations of Shiga toxin-producing Escherichia coli outbreaks linked to leafy greens, United States and Canada. Emerging Infectious Diseases 26 (10): 2319-2328.

Matthews, L., et al. 2006. Heterogeneous shedding of Escherichia coli $\mathrm{O} 157$ in cattle and its implications for control. Proceedings of the National Academy of Sciences of the United States of America 103 (3): 547-552.

May, Peter J. 1991. Reconsidering policy design: Policies and publics. Journal of Public Policy 11 (2): 187-206.

Meagher, Kelsey D. 2019. Public perceptions of food-related risks: A cross-national investigation of individual and contextual influences. Journal of Risk Research 22 (7): 919-935.

Miles, Matthew B., A. Michael Huberman, and Johnny Saldaña. 2013. Qualitative data analysis: A methods sourcebook, 3rd ed. Thousand Oaks, California: Sage Publications. 
Nguyen, Von D., et al. 2015. Increase in multistate foodborne disease outbreaks-United States, 1973-2010. Foodborne Pathogens and Disease 12 (11): 867-872.

Nucci, M.L., C.L. Cuite, and W.K. Hallman. 2009. When good food goes bad: Television network news and the spinach recall of 2006. Science Communication 31 (2): 238-265.

Olimpi, Elissa M., Patrick Baur, Alejandra Echeverri, David Gonthier, Daniel S. Karp, Claire Kremen, Amber Sciligo, and Kathryn T. De Master. 2019. Evolving food safety pressures in California's central coast region. Frontiers in Sustainable Food Systems 3: 102.

Perrow, Charles. 1999. Normal accidents: Living with high-risk technologies, 2nd ed. Princeton, N.J.: Princeton University Press.

Perrow, Charles. 2007. The next catastrophe: Reducing our vulnerabilities to natural, industrial, and terrorist disasters. Princeton, N.J.: Princeton University Press.

Powell, Doug and Ben Chapman. 2018. Almost 6 dozen outbreaks traced to leafy greens since 1995. Food Safety News, April 20.

Robert Koch Institut. 2012. EHEC O104:H4 outbreak in Germany, 2011. https://web.archive.org/web/20201007192047/https://www. rki.de/EN/Content/infections/epidemiology/outbreaks/EHEC_ O104/ehec_O104_inhalt_en.html. Accessed 7 October 2020.

Science for Environment Policy. 2017. The precautionary principle: Decision making under uncertainty. LU: European Commission DG Environment.

Schmit, Julie. 2007. Changes spurred by last fall's E. coli outbreak in fresh spinach. USA Today, September 21.

Shin, Annys. 2006. Outbreaks reveal food safety net's holes; produce growers balk at calls for regulation. Washington Post, December 11.

Shin, Annys, and Sonya Geis. 2006. E. coli probe focuses on 9 Calif. farms. Washington Post, September 20.

Stuart, Diana. 2011. "Nature" is not guilty: Foodborne illness and the industrial bagged salad. Sociologia Ruralis 51 (2): 158-174.

Stuart, Diana, and Michelle R. Worosz. 2012. Risk, anti-reflexivity, and ethical neutralization in industrial food processing. Agriculture and Human Values 29 (3): 287-301.

Stuart, Diana, and Michelle R. Worosz. 2013. The myth of efficiency: Technology and ethics in industrial food production. Journal of Agricultural and Environmental Ethics 26 (1): 231-256.

The Local. 2011a. Bumbling E. coli investigation embarrasses German officials. June 7.

The Local. 2011b. Egyptian seeds firm up as E. coli suspect. July 5.

The Telegraph. 2011. E. coli: Germany admits that locally-grown bean sprouts are cause of outbreak. June 10 .

Thomas, Courtney I. P. 2014. In food we trust: The politics of purity in American food regulation. Lincoln, Nebraska: University of Nebraska Press.

Todd, Ewen C. D., Craig K. Harris, Andrew J. Knight, and Michelle R. Worosz. 2007. Spinach and the media: How we learn about a major outbreak. Food Protection Trends 27 (5): 314-321.

Turner, Kali, Chee Nou Moua, Maha Hajmeer, Amber Barnes, and Michael Needham. 2019. Overview of leafy greens-related food safety incidents with a California link: 1996 to 2016. Journal of Food Protection 82 (3) : 405-414.

U.S. FDA. 1998. Guidance for industry: Guide to minimize microbial food safety hazards for fresh fruits and vegetables. Federal Register 63 (209): 58055-58056.
U.S. FDA. 1999. Guidance for industry: Reducing microbial food safety hazards for sprouted seeds. Federal Register 64 (207): 57893-57902.

U.S. FDA. 2010. 2009/2010 Food Safety Survey. http://web.archive. org/web/20190310073256/https://www.fda.gov/food/foodscienc eresearch/consumerbehaviorresearch/ucm259074.htm. Accessed 9 March 2019.

U.S. Government Accountability Office. 1970. Need to reassess food inspection roles of federal organizations. http://web.archive.org/ web/20190310073333/https://www.gao.gov/assets/80/79388.pdf. Accessed 9 March 2019.

U.S. Government Accountability Office. 1999. U.S. needs a single agency to administer a unified, risk-based inspection system. http://web.archive.org/web/20190310073402/https://www.gao. gov/products/T-RCED-99-256. Accessed 9 March 2019.

Verbruggen, Paul, and Tetty Havinga. 2017. Hybridization of food governance: An analytical framework. In Hybridization of food governance: Trends, types and results, ed. P. Verbruggen and T. Havinga. Northamptom, MA: Edward Elgar.

Vogel, David. 2009. Trading up: Consumer and environmental regulation in a global economy. Cambridge, MA: Harvard University Press.

Vogel, David. 2012. The politics of precaution: Regulating health, safety, and environmental risks in Europe and the United States. Princeton, N.J.: Princeton University Press.

von Wedel, Hedda. 2001. Organisation des gesundheitlichen verbraucherschutzes (schwerpunkt lebensmittel): Empfehlungen der präsidentin des bundesrechnungshofes als bundesbeauftragte für wirtschaftlichkeit in der verwaltung. Berlin, Germany: Kohlhammer.

Ward, April. 2019. New, more stringent food safety practices adopted to prevent outbreaks. California Leafy Greens Marketing Agreement. https://web.archive.org/web/20201023085617/https://lgma. ca.gov/news/new-more-stringent-food-safety-practices-adoptedto-prevent-outbreaks. Accessed 1 June 2021.

Weise, Elizabeth. 2007. Growers pursue safety program; E. coli cases drive push; some skeptical. USA Today, January 26.

Wiener, Jonathan B., and Michael D. Rogers. 2002. Comparing precaution in the United States and Europe. Journal of Risk Research 5 (4): 317-349.

Publisher's Note Springer Nature remains neutral with regard to jurisdictional claims in published maps and institutional affiliations.

Kelsey D. Meagher is a postdoctoral scholar in the Department of Food Science and Technology at the University of California, Davis. A sociologist by training, her research focuses on the intersection of food and agriculture systems, human health, and the environment. Her current work examines food safety governance and food waste/loss. 